\title{
Use of organic acids to improve fractionation of the black soldier fly larvae juice into lipid- and protein-enriched fractions
}

\author{
Lise Soetemans $^{1,2}$ (D) $\cdot$ Maarten Uyttebroek ${ }^{1} \cdot$ Els $^{\prime}$ Hondt $^{1} \cdot$ Leen Bastiaens $^{1}$ (D)
}

Received: 18 January 2019 / Revised: 24 June 2019 / Accepted: 29 June 2019 / Published online: 20 July 2019

(c) The Author(s) 2019

\begin{abstract}
This study focusses on the fractionation of proteins and lipids from insect biomass, more specifically from black soldier fly larvae. Insects are rich in proteins and lipids and offer potential as a protein source for food and feed. Fractionation processes often focus on extracting only one compound (lipid or protein), neglecting the impact of the extraction method on other compounds. The current study aimed at the development of a robust fractionation process for wet insect biomass, targeting enriched protein fractions with higher valuable techno-functional properties as well as enriched lipid fractions. The use of different organic acids was evaluated and compared with an inorganic acid $(\mathrm{HCl})$. A beneficial effect of organic acids on the lipid extraction yield (shift from 35 to $45 \%$ ) was observed, that did not negatively influence the protein extraction efficiency. One organic acid, in particular, lactic acid, increased the lipid purity from 75 to $85 \%$. Protein fractions with a purity of $60 \%$ proteins were achieved and were shown to preserve partial solubility. Use of some organic acids at low $\mathrm{pH}(\mathrm{pH} 2)$ resulted in (1) a higher lipid purity in the lipid-enriched fraction and (2) had similar results in protein fractionation as the inorganic acid. Reproducibility of the fractionation process was proven.
\end{abstract}

Keywords Black soldier fly $\cdot$ Biorefinery $\cdot$ Organic acids $\cdot$ Proteins $\cdot$ Lipids

\section{Introduction}

Insect farming is attracting increasing attention due to the potential of insect biomass as an alternative source for nutritional proteins. It is well documented that the future generation is facing a shortage in protein sources worldwide [1-3] and in a search for new and alternative protein sources, insects have been identified as an innovative possibility [4]. Compared to other animals, insect breeding requires less land and water, produces fewer greenhouse gasses and insects have a low feed conversion ratio [FCR, the amount of feed needed $(\mathrm{kg})$ to obtain one $\mathrm{kg}$ of weight increase in the animal] which is of interest for large-scale breeding [4]. For example, commercially bred yellow mealworms have an FCR of 2.2 on the standard diet and for black soldier fly larvae (BSFL) bred on chicken feed an FCR of 1.8 has been

Leen Bastiaens

leen.bastiaens@vito.be

1 Flemish Institute for Technological Research (VITO), Boeretang 200, 2400 Mol, Belgium

2 Department of Food and Drug, University of Parma, Parma, Italy reported, whereas commercially bred poultry and cereal beef have an FCR of 2.3 and 8.8, respectively [5]. In addition, most insects are rich in proteins (13-77\% depending on species and life stage) [4]. Larvae of the black soldier fly (protein content of $38-41 \%$ [6] in particular have been appointed to be one of the most likely successful insects for feed applications, together with the common housefly, silkworms and the yellow mealworm [4, 7]. However, insects contain besides proteins also significant amounts of lipids and chitin. Chitin is beneficial for feed applications in small amounts [8], but negatively affects the digestibility and utilization of other macro- and micro-nutrients at higher concentration [9-11]. Ozimek et al. [9], for example, found an increasing digestibility of honey bee-protein isolate compared to the digestibility of the whole bee (94\% instead of $71 \%$ ) and hypothesized that the removal of chitin is responsible for the improvement [9]. Hence, there is a possible benefit in separation of insect biomass to generate protein fractions with reduced chitin content. In addition, separate protein and lipid extracts will make it possible to reach a target protein/lipid content or ratio in feed diets. Studies have also indicated that human consumers are more likely to accept insectsbased food when extracts are used as an ingredient [2, 12]. 
Based on a literature search, Nongonierma and FitzGerald [13] concluded that the current extraction procedures for insect proteins generally includes the following steps: (1) drying of the insect biomass, (2) homogenization, (3) defatting, (4) protein solubilization, (5) isoelectric precipitation of the proteins and (6) protein solubilization followed by a possible drying step [13]. In general, insects are freeze-dried $[12,14-16]$ and grinded into smaller particles for better solvent contact. Defatting (step 3) is commonly performed with organic solvents such as hexane or ethanol [13], but successful supercritical $\mathrm{CO}_{2}$ defatting has also been reported [17, 18]. In the fourth step, proteins are solubilized to separate soluble proteins from non-soluble matter (such as chitin). Generally, the $\mathrm{pH}$ of insects biomass is increased to perform an alkaline extraction in aqueous conditions [13]. During the fifth step, soluble proteins are precipitated by lowering the $\mathrm{pH}$ to the isoelectric point, which is generally around $\mathrm{pH} 5$. In this way, the purity of the resulting protein fraction can be increased. The last step includes resolubilization by bringing the $\mathrm{pH}$ to neutral and drying [13]. However, literature indicates that not all steps are always included in extraction procedures and details of individual steps can vary considerably. For example, Yi et al. [19] did not perform the predrying step but used frozen insect and water to homogenize, added a filtration step to remove the chitin, while defatting was performed by centrifugation at $4{ }^{\circ} \mathrm{C}$. Some studies only perform step 1-4 [16] or add an additional step such as filtration or acidifying the non-soluble fraction after alkaline $\mathrm{pH}$ [20]. More traditional methods to extract lipids, for example hydraulic pressing, solvent extraction and heat extraction, focus only on step 1-3 without a regard for the preservation of techno-functional proteins [21]. Heat extraction, also called rendering, can be performed on wet material; whereas solvent extraction and hydraulic pressing are best performed on dry material. Rendering, although very successful in extracting lipids, can cause protein denaturation, since high temperature and pressurized conditions are involved [22].

The first three steps of the procedure compiled by Nongonierma and FitzGerald [13] can be disadvantageous when applications in food and feed industries and upscaling are intended. Drying is often an energy-consuming step and difficult to scale up when no high temperatures are allowed [21]. In addition, solvent fat extraction requires pre-dried insect biomass and is often not eco-friendly or food-friendly $[13,23]$. Despite the high yield of soluble proteins, alkaline conditions can impact the protein quality. For instance, antinutritional compounds can be formed such as lysinoalanine that negatively impacts protein digestibility and amino acid availability in food [24]. To make the fractionation procedure more applicable for feed/food industries on large scale, this study focusses on avoiding a drying step and possible losses in nutritional value. Since organic acids are allowed in the feed and food industry, the paper investigates the performance of fractionation at low $\mathrm{pH}$ with the use of organic acids where lipids are removed without the use of solvents. Earlier, Liang and Hultin [25] studied the impact of citric, lactic and malic acid on the separation of phospholipids lipids from solubilized proteins in fish muscle [25]. A positive impact of the organic acids was reported. Malic acid gave the best results for lipid removal, followed by citric acid and lactic acid. For protein extraction, citric- and malic acid resulted in the same yield, but a lower yield was noted with lactic acid [25]. The focus of that paper was on separating phospholipids from membrane proteins; while in the current study, all lipid classes are present and expected to separate. In addition, $\mathrm{HCl}$ is traditionally used for solubilization of proteins in the acid region; while this paper investigates the potential of organic acids. The current study aimed to develop a method to separate proteins from lipids in an aqueous environment while preserving the techno-functionalities of the proteins. For all obtained fractions, the distribution of lipids and proteins was evaluated to investigate not only the purity but also the maximum yield. The preservation of the techno-functionalities was evaluated based on the solubility of the proteins. To the best of our knowledge, such study has not been published before.

\section{Materials and methods}

\section{Materials}

Living black soldier fly larvae (BSFL), bred on broiler feed, were kindly provided by Millibeter (Belgium). BSFL juice was obtained after a mechanical separation (based on WO 2019081067), where the exoskeletons were removed. The insect juice was frozen immediately and stored at $-20^{\circ} \mathrm{C}$ in vacuum bags till use. The bags were defrosted in room temperature water for $10 \mathrm{~min}$ before use. Lactic acid (Alfa Aesar 85.0-90.0\%), acetic acid (Merck Millipore, 30\%), citric acid (Merck, citric acid monohydrate), succinic acid (Amresco), valeric acid (Aldrich, >99\%), oxalic acid (JT Baker, oxalic acid dihydrate) and $\mathrm{HCl}$ (Merck, 37\%) were tested. During Soxhlet, diethyl ether (Merck) was used as extraction media.

\section{Fractionation procedure}

The extraction media that were evaluated as triplicates are summarized in Table 1. Defrosted insect juice was mixed with the solvent at a liquid $(w)$ : $s o l i d(w)$ ratio of $17.6 \pm 0.5$ (200 $\mathrm{ml}$ assay). A concentration of $0.5-\mathrm{M}$ organic acid was used, except for valeric acid which was used at $0.33 \mathrm{M}$ (because of the saturation point). For some test conditions, the $\mathrm{pH}$ was kept at $\mathrm{pH} 2$ by measuring the $\mathrm{pH}$ every $10 \mathrm{~min}$ and adjusting it with $2.5-\mathrm{M} \mathrm{HCl}$. These conditions are indicated by ' $+\mathrm{HCl}^{\prime}$ ' in Table 1 . The mixture was stirred for $30 \mathrm{~min}$ in total at $100 \mathrm{rpm}$ on a shaking plate (Gerhardt 
Table 1 Extraction media and characteristics used in this study

\begin{tabular}{lllll}
\hline Condition & Solvent & $\mathrm{pH}$ of acids & $\begin{array}{l}\mathrm{pH} \text { of acid-juice mixture } \\
\text { before } \mathrm{HCl} \text { correction }\end{array}$ & $\begin{array}{l} \pm \text { Amount of } \\
\mathrm{HCl}(2.5 \mathrm{M}) \\
\text { needed }\end{array}$ \\
\hline $1^{\mathrm{a}}$ & Water & & 6.9 & \\
2 & Water $+\mathrm{HCl}$ & 2.1 & $16 \mathrm{~g}$ \\
3 & Lactic acid & 1.9 & 3.3 & $10 \mathrm{~g}$ \\
4 & Lactic acid $+\mathrm{HCl}$ & 1.9 & 3.3 & $15 \mathrm{~g}$ \\
5 & Acetic acid $+\mathrm{HCl}$ & 2.5 & 4.0 & $9.5 \mathrm{~g}$ \\
6 & Citric acid $+\mathrm{HCl}$ & 1.9 & 2.4 & $16 \mathrm{~g}$ \\
7 & Succinic acid $+\mathrm{HCl}$ & 2.3 & 3.6 & $17 \mathrm{~g}$ \\
$8^{\mathrm{a}}$ & Valeric acid $+\mathrm{HCl}$ & 2.6 & 4.6 & \\
$9^{\mathrm{a}}$ & Oxalic acid $+\mathrm{HCl}$ & 1.3 & 1.6 & \\
\hline
\end{tabular}

The mixture was stirred at $100 \mathrm{rpm}$ for $30 \mathrm{~min}$ in a 17.6 liquid: solid (w:w) ratio (200 $\mathrm{ml}$ assay)

${ }^{\mathrm{a}}$ Conditions not studied in detail

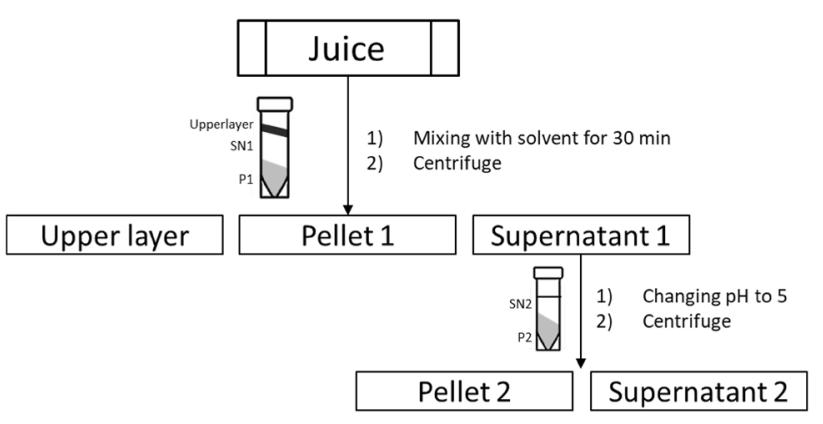

Fig. 1 Scheme of extraction procedure

laboshake) at room temperature. After swing out centrifugation (Eppendorf 5810-A-4-81 rotor) at room temperature (3220 g, $30 \mathrm{~min}$ ), three layers were obtained (Fig. 1). The upper layer was scooped off with a spatula. The supernatant (SN1) was decanted and the pellet (pellet 1) was collected and resuspended at $\mathrm{pH} 7$. The $\mathrm{SN} 1$ fraction was adjusted to $\mathrm{pH} 5$ with $\mathrm{NaOH}(40 \mathrm{v} \%$ or $50 \mathrm{w} \%$ ) and was subsequently centrifuged at room temperature $(3220 \mathrm{~g}$, $15 \mathrm{~min}$ ) to obtain two fractions, being a supernatant (SN2) and a pellet (pellet 2). Both fractions were resuspended at $\mathrm{pH} 7$. Selected tests were repeated at a fixed temperature of $25^{\circ} \mathrm{C}$ using angled head centrifugation (Thermo Scientific, Sorvall lynx $6000-F 14-14 \times 50$ cy rotor).

The distribution of the obtained fractions (as dry weight, DW) was evaluated by calculating non-dialyzed yield (NDY) for the different fraction using the following formula (1):

$\mathrm{NDY} \%=\frac{\text { fraction }(\mathrm{g} D W)}{\text { juice }(\mathrm{g} \text { DW })} \times 100$

During the screening test, the upper layer (rich in oil) and pellet 2 (rich in proteins) received most attention. For a selection of well-performing conditions, a more detailed mass balance was established after dialyzing all four fractions (Spectrum $^{\mathrm{TM}}$ Labs Spectra/Por ${ }^{\mathrm{TM}} 61000 \mathrm{D}$ MWCO Standard RC Pre-wetted Dialysis Kits). Dialyzed yield, recovery and lipid/protein distribution were calculated using the following formulas (2), (3) and (4):

Dialyzed yield $\%=\frac{\text { fraction }(>1 \mathrm{kDa})(\mathrm{g} \mathrm{DW})}{\text { juice }(>1 \mathrm{kDa})(\mathrm{g} \mathrm{DW})} \times 100$

Recovery $(\%)=$ Yield upper layer $(\%)+$ yield pellet $1(\%)$

$$
+ \text { yield pellet } 2(\%)+\text { yield supernatant } 2(\%)
$$

Lipid or protein distribution $\%$

$$
=\frac{\text { amount of lipid or protein in fraction }(g)}{\text { amount of lipid or protein in juice }(g)} \times 100
$$

\section{Sample characterization}

Dry weight was measured either after oven drying at $105^{\circ} \mathrm{C}$ (juice and upper layer) for $48 \mathrm{~h}$ or after freeze-drying (pellet 1, pellet 2 and SN2) (Christ, gamma 1-16 LSC) for $36 \mathrm{~h}$. Ash content was determined gravimetrically after incineration $\left(550^{\circ} \mathrm{C}\right)$ in a muffle furnace. The crude lipid content was determined by Soxhlet extraction with diethyl ether for $6 \mathrm{~h}$ and expressed on dry weight. Quantification of the chitin content was performed as described by D'Hondt et al. (D'Hondt et al., submitted). Briefly, chitin was hydrolyzed to glucosamine and acetate that were subsequently quantified by LC-MS and HPLC-RID, respectively. The sample was hydrolyzed with $6 \mathrm{~N} \mathrm{HCl} \mathrm{for} 6 \mathrm{~h}$ at $110{ }^{\circ} \mathrm{C}$. Glucosamine was determined by UPLC-MS/MS analysis (Waters UPLC BEH HILIC $2.1 \times 100 \mathrm{~mm}, 1.7 \mu \mathrm{m}$ column at $40{ }^{\circ} \mathrm{C}$, isothermal gradient elution using water with (A) $20-\mathrm{mM}$ ammoniumformiate and $0.1 \%$ formic acid $(\mathrm{pH}=3)$ and acetonitrile (B) with $0.1 \%$ formic acid with gradient settings: 5-25\% A (0-3 min), 25\% A (3-4 min), 25-5\% A (4-4.1 min), 
5\% A (4.1-7 $\mathrm{min}$ ) at $0.4 \mathrm{ml} / \mathrm{min}$ at $40{ }^{\circ} \mathrm{C}$ ). Peak detection and quantification were done using a triple quadrupole MS operated in multiple reaction monitoring mode. Crude protein content of the fractions was calculated based on nitrogen measurements (Dumas method, Elementar, vario EL cube) using the standard 6.25 correction factor and expressed on dry weight. $\mathrm{pH}$ solubility curves were measured at $\mathrm{pH}$ values ranging between $\mathrm{pH} 2$ and $\mathrm{pH}$ 10. Dispersions in demineralized water were stirred at different $\mathrm{pH}$ for $30 \mathrm{~min}$; then the $\mathrm{pH}$ was checked and adjusted if needed with $0.1 \mathrm{M} \mathrm{NaOH}$ or $0.1 \mathrm{M} \mathrm{HCl}$, followed by another $30 \mathrm{~min}$ of stirring. Afterwards, samples were centrifuged at $4{ }^{\circ} \mathrm{C}$ for $20 \mathrm{~min}$ at $5910 \mathrm{~g}$. The total nitrogen was determined by a chemiluminescence detector (Multi N/C 3100 Analytik Jena). The sample was oxidized by catalytic combustion in an oxygen atmosphere at $800^{\circ} \mathrm{C}$, to produce nitrogen oxides as is described by EN 12260:2003 [water quality—determination of nitrogen - determination of bound nitrogen ( $\mathrm{TNb}$ ), following oxidation to nitrogen oxides]. The formed measuring gas was dried and entered the reaction chamber of the chemiluminescence detector. There, the nitrogen monoxide present in the measuring gas was oxidized with ozone into activated nitrogen dioxide. By emitting light photons (luminescence), the molecules of the nitrogen dioxide returned to their original state. The luminescence was detected using a photomultiplier and is proportional to the nitrogen monoxide concentration. Sample vials were filled with about $25-\mathrm{ml}$ sample and placed into the sample carrousel. About $1000 \mu \mathrm{l}$ of sample was injected in the system. The catalytic combustion of the sample in an oxygen atmosphere $(160 \mathrm{mbar})$ was carried out at $800{ }^{\circ} \mathrm{C}$. A linear calibration curve between 1 and $10 \mathrm{mg} / \mathrm{l}$ of nitrogen was set up using a mixture of ammonium sulfate (Merck) and potassium nitrate (Merck) at five concentration levels (1-2.5-5-7.5 and $10 \mathrm{mg} \mathrm{N} / \mathrm{l}$ ). Solubility was expressed as percent of protein in the supernatant relative to the protein content of the sample. The total protein solubility at a specific $\mathrm{pH}$ (of all proteins in the juice) after fractionation was determined by adding the solubilities of the different fractions according to formula (5). The fraction solubility for a certain $\mathrm{pH}$ was calculated based on formula (6), where ' $F$ ' stands for the fraction (pellet 1, pellet 2, SN2).

\section{Results and discussion}

\section{Characterization of the BSFL juice}

The BSFL juice used for this study had a dry weight of $26 \%$. The crude protein and lipid content based on dry weight was $38 \%$ and $35 \%$, respectively, as indicated in Table 2 along with other composition data. Chitin content of the juice was $0.52 \%$ which is much lower compared to BSFL that have a chitin content between $4.4 \%$ and $9.1 \%$ [26, 27]. The solubility curve of the proteins in the insect juice was U-form shaped (see Fig. 4), indicating that BSFL proteins have a high solubility at low and high $\mathrm{pH}(90 \%$ soluble at $\mathrm{pH} 2$ and $80 \%$ at $\mathrm{pH} 9)$ and an isoelectric point around $\mathrm{pH}$ 5. Earlier, Bußler et al. [20] reported a solubility curve for BSFL with a different pattern. The protein solubility of the larvae meal was only $40 \%$ at $\mathrm{pH} 2$ and $\mathrm{pH} 9$ and a minimum was reached at $\mathrm{pH} 4$. However, the exoskeleton (containing chitin) was included in this experiment [20]. Chitin is a non-soluble polymer containing nitrogen that may lead to underestimation of the protein solubility if not taken into account when converting nitrogen measurements into protein content. To the best of our knowledge, no solubility curves for BSFL juice (without the exoskeletons) have been described before in literature. The findings of Zielińska et al. [14] on solubility for the mealworm proteins (extracted by alkaline isoelectric point precipitation) Tenebrio molitor, the cricket Gryllodes sigillatus and grasshopper Schistocerca gregaria were more similar to the results obtained in the current study. The isoelectric point for these insects proteins (without exoskeleton) was situated around $\mathrm{pH}$ 5 and a solubility up to $90 \%$ was reached at $\mathrm{pH} 2$ and 8 [14].

\section{Distribution of lipids and proteins among the fractions obtained}

Even though protein extractions at alkaline $\mathrm{pH}$ result in a high amount of soluble proteins, protein digestibility and nutritional value can decrease [28]. Hence, protein fractionation at acid pH may be a better approach. Based on the solu-

Total solubility $(\%)=\frac{(\text { fraction solubility of P1 }+ \text { fraction solubility of } \mathrm{P} 2+\text { fraction solubility of SN2) }}{100 \mathrm{~g} \text { juice } \times \text { crude protein of juice }\left(\frac{\mathrm{g} \text { protein }}{100 \mathrm{~g} \text { juice }}\right)} \times 100$

Fraction solubility (g soluble protein)

$$
\begin{aligned}
= & 100 \mathrm{~g} \text { juice } \times \text { yield of } F\left(\frac{\mathrm{g} \text { fraction }}{100 \mathrm{~g} \text { juice }}\right) \\
& \times \text { crude protein content of } F\left(\frac{\mathrm{g} \text { protein }}{100 \mathrm{~g} \text { fraction }} \%\right) \\
& \times \text { solubility }\left(\frac{\mathrm{g} \text { protein soluble }}{100 \mathrm{~g} \text { protein }}\right) .
\end{aligned}
$$

bility curve, it can be suggested that at $\mathrm{pH} 2$, proteins can be separated from other non-soluble particles with only $10 \%$ of protein loss. To separate the proteins from other soluble molecules in a subsequent step, the $\mathrm{pH}$ can be adjusted to 5 to precipitate about $60 \%$ of the proteins. This fractionation approach was verified using different organic acids. Since the $\mathrm{pH}$ of the mixtures after adding the organic acids raised and was different over all treatment (see Table 1), $\mathrm{HCl}$ was used to insure all treatments had the same $\mathrm{pH}$. 
Table 2 Proximate composition of black soldier fly larvae juice (without the exoskeletons) on dry matter basis (mean $\pm \mathrm{SD}, n=3$ )

\begin{tabular}{lr}
\hline BSFL juice (without exoskeletons) & $\%$ \\
\hline Dry weight & $26.45 \pm 0.42$ \\
Protein content & $38.16 \pm 0.53$ \\
Lipid content & $35.98 \pm 0.77$ \\
Ash content & $10.07 \pm 0.52$ \\
Chitin content & $0.52 \pm 0.06$ \\
\hline
\end{tabular}

Nine test conditions were set up to evaluate the performance of six different organic acids, being lactic acid, acetic acid, citric acid, succinic acid, valeric acid, and oxalic acid. The aim was to fractionate the juice into a lipidenriched fraction and a protein-enriched fraction. The distribution of the lipids and proteins among the four fractions is visualized in Fig. 2. The lipids were predominantly present in the upper layer except for condition 1, 8 and 9 (Fig. 2a). For all other conditions, on average, $64 \%$ of all lipids were concentrated in this fraction with $75 \%$ for condition 6 (citric acid) and 73\% for condition 4 (lactic acid). Figure $2 b$ illustrates that the proteins were distributed over all fractions but were concentrated predominantly in pellet 2 (up to $48 \%$, in particular for condition 2, 5 and 6 )

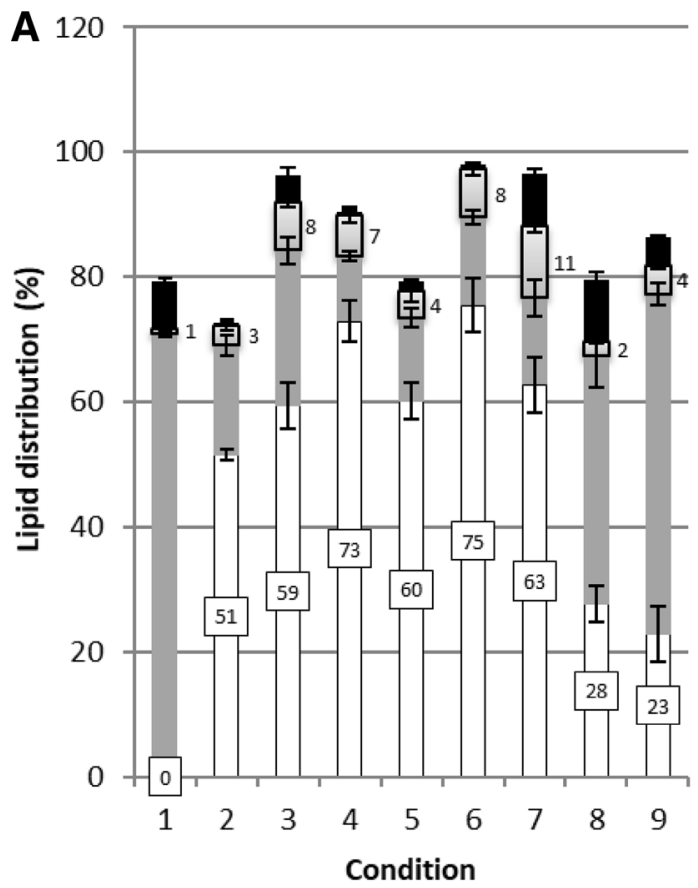

$\square$ upper layer $\square$ pellet $1 \square$ pellet $2 \square$ SN2

Fig. 2 Lipid (a) and protein (b) distribution of the four generated fraction (mean $\pm \mathrm{SD}, n=3$ ). Distribution over the obtained fraction after mixture was stirred at $100 \mathrm{rpm}$ for $30 \mathrm{~min}$ in a 17.6 liquid: solid (w:w) ratio (200 $\mathrm{ml}$ assay), the condition 1: water, condition 2: and SN2 (up to 48\%). The impact of acid versus neutral $\mathrm{pH}$ during extraction could be evaluated by comparing the results obtained under condition 1 and 2 . When working in an acidic environment, an upper layer was formed separating lipids that were first located in pellet, and more proteins could be collected in pellet 2 (13\% versus $45 \%$ ). This result was expected based on the solubility curve of the juice (Fig. 4). Comparison between conditions 3 and 4 also indicated that lactic acid at $\mathrm{pH} 2$ was more beneficial than at $\mathrm{pH}$ 3.3. At $\mathrm{pH} 2$ (condition 4), more lipids were collected in the upper layer and the protein distribution altered towards proteins in pellet 2 and less in the upper layer. The influence of organic acids was studied by comparing them to an inorganic acid $(\mathrm{HCl})$ at the same $\mathrm{pH}$ (condition 2). When only inorganic acid was used (condition 2), the distribution of lipids was less in the upper layer compared to four out of six organic acids, indicating an added value of these specific acids in collecting lipids in the upper layer. The difference was less pronounced in the protein distribution. In conclusion, the results of the screening test indicate that conditions 2, 4, 5, 6 and 7 may be of interest for fragmentation of insect juice. When pure lipid fractions are desired, condition 4 (lactic acid) would be superior to condition 6 or 7 because of a lower protein distribution in the upper layer. Condition 5 (acetic acid)

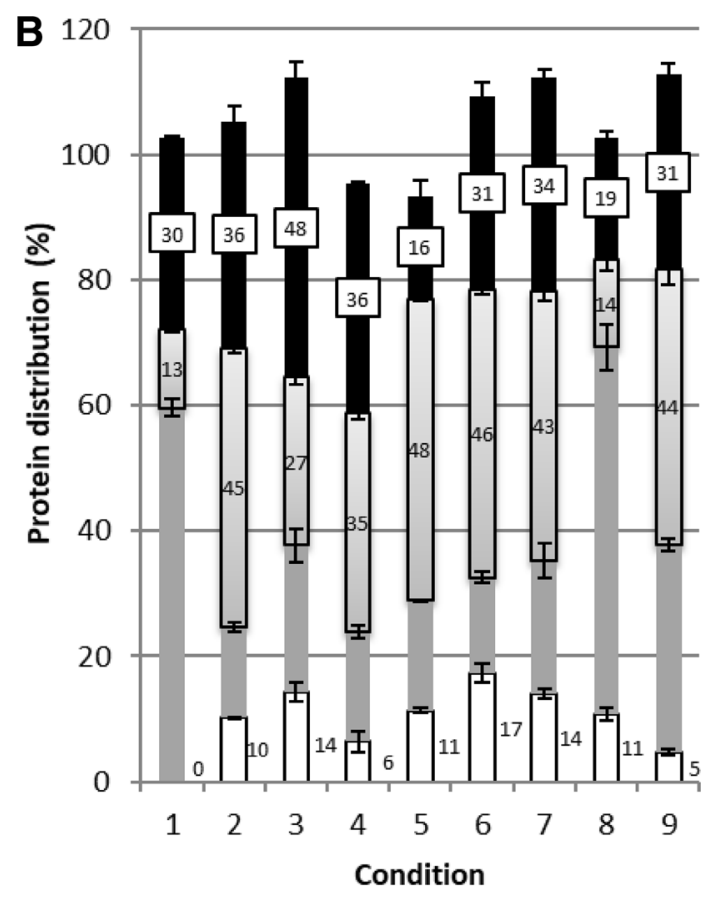

$\square$ upper layer $\square$ pellet $1 \square$ pellet $2 \square$ SN2

water $+\mathrm{HCl}$, condition 3: lactic acid, condition 4: lactic acid $+\mathrm{HCl}$, condition 5: acetic acid $+\mathrm{HCl}$, condition 6: citric acid $+\mathrm{HCl}$, condition 7: succinic acid $+\mathrm{HCl}$, condition 8: valeric acid $+\mathrm{HCl}$, condition 9: oxalic acid $+\mathrm{HCl}$ 
resulted in a lower distribution of proteins in the upper layer, same as condition 2, but still a high distribution of protein in pellet 2 was noted (48\%).

\section{Yield and purity}

In the previous section, the impact of organic acids on the distribution of lipids and proteins among the four generated fractions was evaluated. When envisioning the use of the fractions towards certain applications, also the size of the fraction (yield) and the concentration of lipids and/ or proteins in the fraction (purity) are important criteria to evaluate the added value of organic acid assisted extractions. The compilation of accurate mass balances, however, was proven to be challenging due to the acids and alkaline that were added during the extraction. These chemicals were distributed over all fractions and were partially lost via evaporation during drying of the fractions. Further, as proteins and lipids only represented $74 \%$ of DW juice, mass balances prepared based exclusively on these compounds are not accurate. Two types of mass balances were calculated to make best estimates for the yield of the different fractions. Firstly, NDYs (non-dialyzed yields) were calculated based on the dry weight amounts of the fractions after drying relative to the dry weight of juice used, which provides a realistic view of the obtained fractions. Next, for a selection of six most promising conditions (condition 2, 3, 4, 5, 6 and 7), yields based on the weight of dialyzed fractions were calculated relative to the weight of the dialyzed juice (named dialyzed yield) to verify the fate of the juice among the four fractions (see Table 3). Dialysis of the juice fraction resulted in a $79.0 \pm 3.3 \%$ recovery. Conditions 1,8 and 9 were excluded because of the poor lipid distribution. The added yields of the four fractions ranged between 107 and $270 \%$, and between 70 and $98 \%$ for non-dialysed and dialyses fractions, respectively. The total recovery based on dialyzed yield suggested some losses during the extraction procedure. Gas development, possibly caused by for instance enzymatic or microbial activity, was noticed during the extraction procedure. This may have contributed to the losses of mass. For the upper layer, which was observed for all test conditions except for condition 1, the non-dialyzed yield varied between 12 and 39\% DW of the initial juice and the dialyzed yield was slightly higher than onethird of the juice. The lipid content of the upper layer was between 66 and $85 \%$. The highest percentage was obtained using lactic acid at $\mathrm{pH} 2$ (condition 4), followed by acetic acid (condition 5), and lactic acid with no additional $\mathrm{HCl}$ (condition 3). In addition, condition 4 realized an upper layer with a very small protein impurity (8\%). The highest yield for the lipid-rich upper layer was obtained with succinic acid (46\%, condition 7) followed by citric acid (41\%, condition 6). Yet, these were not the most pure fractions based on lipid content and thus not seen as an improvement of the fractionation procedure. Condition 4 , on the other hand, contained a significantly higher $\%$ of lipids (73\% distribution) in the upper layer compared to condition 7 (63\% distribution) with a slightly lower dialyzed yield (37\% versus $46 \%)$.

With respect to protein purity, an enrichment of the protein content was obtained for all conditions in pellet 2 . Conditions $9,5,1$ and 2 resulted in a protein content higher than $50 \%$. Despite its higher protein content in pellet 2 for condition 1 , water alone as extraction media is not advisable since the non-dialyzed yield was only $8 \%$. Protein fractions with low lipid content $(<5 \%)$ were observed for conditions 2 and 5 . The dialyzed yield of the protein-rich pellet 2 was on average $25 \%$ and was maximized with conditions 2,6 and 7 to $27 \%$. Comparing non-dialyzed and dialyzed yields for conditions 6 and 7 revealed that significant amounts of compounds smaller than $1 \mathrm{kDa}$ were present. This makes these fractions, despite their high non-dialyzed yield (48\% and 39\%, respectively) less interesting than condition 2 for the fractionation procedure. For both pellets 1 and 2, the sum of lipid and protein content was on average $\pm 55 \%$, indicating that other compounds were concentrated in these fractions.

Fraction pellet 1 contained lower amounts of lipid and protein compared to the juice. These concentrations were even lower in fraction SN2, especially for lipids. The nondialyzed yields of SN2 were significantly higher compared to the dialyzed yield. This indicates that SN2 consisted mostly of compounds smaller than $1 \mathrm{kDa}$ and that only maximum $9 \%$ of the dialyzed juice was distributed in this fraction. In addition, this effect is also notable, but less pronounced with pellet 1 (e.g., conditon 5, the yield decreased from 23.5 to $14.2 \%$ ) and pellet 2 (the yield decreased from 32.7 to $23.2 \%$ for condition 5). These results indicate that a filtration step of these fractions will further purify the sample and thus also increase the protein/lipid content. Filtration would result in the removal of organic and inorganic salt which can have a positive effect on feed applications. However, also other compounds such as small peptides, amino acids on other micro-nutrients would be lost.

Comparison between conditions 3 and 4 confirms the conclusions made based on the lipid and protein distribution. A more acidic $\mathrm{pH}$ resulted in a higher dialyzed yield of pellet $2(24 \%$ versus $18 \%)$ with a lower lipid content $(8 \%$ versus $12 \%$, whereas the protein content was similar. In addition, the results for these conditions also indicate that a low $\mathrm{pH}$ favored lipid fractionation since the lipid content was higher in the upper layer at $\mathrm{pH} 2$ (85\% versus $78 \%)$. Literature on the BSFL reports the presence of a large amount of free fatty acids, depending on the killing method [29, 30]. Ushakova et al. [29] reported $87 \%$ of lipids to be free fatty acids when the larvae were killed by freezing. Caligiani et al. 
Table 3 Extraction NDY, yield and crude protein and lipid content on dry basis of the four extracted fractions (mean $\pm \mathrm{SD}, n=3$ )

\begin{tabular}{|c|c|c|c|c|c|c|}
\hline Fraction & Condition & Acid & $\begin{array}{l}\text { Average non-dia- } \\
\text { lyzed yield (\%) }\end{array}$ & $\begin{array}{l}\text { Average dialyzed } \\
\text { yield }(\%)\end{array}$ & $\begin{array}{l}\text { Average crude protein } \\
\text { content }(\%)\end{array}$ & $\begin{array}{l}\text { Average crude } \\
\text { lipid content } \\
(\%)\end{array}$ \\
\hline \multirow[t]{9}{*}{ Upper layer } & 1 & Water & $*$ & $*$ & $*$ & $*$ \\
\hline & 2 & $\mathrm{HCl} \mathrm{pH} 2$ & $18.62 \pm 0.40$ & $35.72 \pm 1.19$ & $16.02 \pm 0.34$ & $75.05 \pm 1.28$ \\
\hline & 3 & Lactic acid & $28.22 \pm 1.35$ & $29.35 \pm 1.40$ & $19.31 \pm 1.15$ & $75.57 \pm 1.14$ \\
\hline & 4 & Lactic acid pH 2 & $30.77 \pm 1.08$ & $37.30 \pm 1.26$ & $8.03 \pm 2.27$ & $85.27 \pm 1.22$ \\
\hline & 5 & Acetic acid pH 2 & $27.83 \pm 0.73$ & $30.08 \pm 1.96$ & $15.54 \pm 0.95$ & $77.64 \pm 1.72$ \\
\hline & 6 & Citric acid pH 2 & $39.58 \pm 0.57$ & $41.05 \pm 0.85$ & $16.77 \pm 1.34$ & $68.61 \pm 4.47$ \\
\hline & 7 & Succinic acid pH 2 & $32.93 \pm 1.99$ & $45.89 \pm 0.52$ & $16.38 \pm 0.35$ & $68.48 \pm 0.88$ \\
\hline & 8 & Valeric acid pH 2 & $17.19 \pm 1.58$ & $*$ & $24.00 \pm 0.60$ & $66.24 \pm 0.94$ \\
\hline & 9 & Oxalic acid pH 2 & $12.87 \pm 1.90$ & $*$ & $13.81 \pm 0.70$ & $72.55 \pm 4.25$ \\
\hline \multirow[t]{9}{*}{ Pellet 1} & 1 & Water & $70.00 \pm 1.35$ & $*$ & $32.69 \pm 0.19$ & $22.14 \pm 0.52$ \\
\hline & 2 & $\mathrm{HCl} \mathrm{pH} 2$ & $18.62 \pm 0.42$ & $10.47 \pm 0.46$ & $29.60 \pm 0.83$ & $33.82 \pm 2.49$ \\
\hline & 3 & Lactic acid & $29.37 \pm 3.32$ & $22.44 \pm 2.53$ & $30.73 \pm 0.04$ & $30.68 \pm 1.62$ \\
\hline & 4 & Lactic acid pH 2 & $24.07 \pm 4.32$ & $14.16 \pm 2.42$ & $28.52 \pm 5.13$ & $16.01 \pm 3.38$ \\
\hline & 5 & Acetic acid pH 2 & $23.52 \pm 0.84$ & $14.19 \pm 1.53$ & $28.48 \pm 0.92$ & $20.64 \pm 1.82$ \\
\hline & 6 & Citric acid pH 2 & $24.23 \pm 0.94$ & $13.65 \pm 0.83$ & $24.17 \pm 0.41$ & $20.93 \pm 0.90$ \\
\hline & 7 & Succinic acid pH 2 & $27.77 \pm 3.80$ & $16.91 \pm 3.74$ & $29.38 \pm 0.17$ & $18.02 \pm 1.67$ \\
\hline & 8 & Valeric acid pH 2 & $69.75 \pm 2.46$ & $*$ & $32.21 \pm 0.89$ & $23.40 \pm 2.24$ \\
\hline & 9 & Oxalic acid pH 2 & $56.60 \pm 1.72$ & $*$ & $22.52 \pm 0.31$ & $39.69 \pm 0.21$ \\
\hline \multirow[t]{9}{*}{ Pellet 2} & 1 & Water & $8.20 \pm 0.46$ & & $59.26 \pm 0.94$ & $17.69 \pm 0.76$ \\
\hline & 2 & $\mathrm{HCl} \mathrm{pH} 2$ & $30.11 \pm 0.34$ & $27.43 \pm 3.01$ & $56.90 \pm 1.53$ & $3.93 \pm 1.21$ \\
\hline & 3 & Lactic acid & $22.92 \pm 0.95$ & $18.21 \pm 0.75$ & $44.88 \pm 0.65$ & $12.20 \pm 0.94$ \\
\hline & 4 & Lactic acid pH 2 & $30.80 \pm 0.85$ & $23.50 \pm 1.22$ & $43.65 \pm 0.83$ & $7.62 \pm 1.31$ \\
\hline & 5 & Acetic acid pH 2 & $32.68 \pm 0.33$ & $23.21 \pm 1.25$ & $56.23 \pm 0.46$ & $4.71 \pm 1.87$ \\
\hline & 6 & Citric acid pH 2 & $47.60 \pm 0.48$ & $27.40 \pm 0.97$ & $37.06 \pm 0.50$ & $5.76 \pm 0.75$ \\
\hline & 7 & Succinic acid pH 2 & $38.46 \pm 1.58$ & $27.33 \pm 1.96$ & $42.94 \pm 3.01$ & $10.66 \pm 1.06$ \\
\hline & 8 & Valeric acid pH 2 & $11.23 \pm 0.79$ & $*$ & $47.94 \pm 2.56$ & $9.13 \pm 1.93$ \\
\hline & 9 & Oxalic acid pH 2 & $29.86 \pm 1.72$ & $*$ & $56.58 \pm 1.45$ & $6.18 \pm 0.40$ \\
\hline \multirow[t]{9}{*}{$\mathrm{SN} 2$} & 1 & Water & $28.37 \pm 0.47$ & $*$ & $41.30 \pm 0.65$ & $6.26 \pm 0.67$ \\
\hline & 2 & $\mathrm{HCl} \mathrm{pH} 2$ & $39.88 \pm 2.52$ & $3.05 \pm 0.88$ & $34.71 \pm 0.19$ & $0.25 \pm 0.09$ \\
\hline & 3 & Lactic acid & $98.61 \pm 5.41$ & $6.27 \pm 0.34$ & $18.63 \pm 0.23$ & $1.55 \pm 0.42$ \\
\hline & 4 & Lactic acid pH 2 & $87.70 \pm 4.67$ & $8.54 \pm 0.79$ & $16.00 \pm 0.98$ & $0.25 \pm 0.09$ \\
\hline & 5 & Acetic acid pH 2 & $34.65 \pm 6.06$ & $2.80 \pm 1.01$ & $18.15 \pm 0.57$ & $1.48 \pm 0.33$ \\
\hline & 6 & Citric acid pH 2 & $158.91 \pm 13.27$ & $5.89 \pm 1.57$ & $7.44 \pm 0.06$ & $0.20 \pm 0.04$ \\
\hline & 7 & Succinic acid pH 2 & $122.91 \pm 3.82$ & $7.43 \pm 0.72$ & $10.67 \pm 0.16$ & $2.49 \pm 0.18$ \\
\hline & 8 & Valeric acid pH 2 & $49.99 \pm 2.52$ & $*$ & $15.00 \pm 0.77$ & $8.03 \pm 0.75$ \\
\hline & 9 & Oxalic acid pH 2 & $76.23 \pm 4.70$ & $*$ & $15.60 \pm 0.10$ & $2.54 \pm 0.13$ \\
\hline
\end{tabular}

Bold: fraction is enriched in protein or lipid

*Not determined

[30] found a free fatty acid content of $78 \%$ in larvae that were frozen. However, they stated that the storage length influenced the free fatty acids content (35\% immediately after freezing, $90 \%$ after 2 months in frozen storage). Larvae that were first killed by blanching only showed traces of free fatty acids. The larvae in the current study were not frozen but mechanically killed. During this treatment, it cannot be excluded that lipases were activated and free fatty acids were formed, but based on TLC analyses, they were not found to be dominant (data not shown). A possible explanation for a better separation in a more acidic environment is that these free fatty acids may become protonated and thus become less soluble in water. In addition, the acid environment will change the structure of proteins and perhaps decrease emulsifying properties making separation more easily. Focusing on the added value of organic acids assisted extraction of 
lipids, the dialyzed yields demonstrate that all organic acids (at $\mathrm{pH}$ 2) except for acetic acid (condition 5) increased the upper layer yield compared to $\mathrm{HCl}$ (condition 2). The inorganic acid $(\mathrm{HCl})$ treatment at $\mathrm{pH} 2$ resulted in a lipid content of $75 \%$. For most organic acids, a similar or slightly lower lipid content was obtained, except for lactic acid (condition 4). Here, an increased lipid content (85\%) and as such an increased purity (lower protein content) was observed. A similar observation was stated by Liang and Hultin [32] where organic acid had a beneficial effect on separating phospholipids from soluble fish proteins. A better phospholipid removal was noticeable compared to a water treatment (both adjusted to the same $\mathrm{pH}$ with $\mathrm{HCl}$ ). Malic acid gave the best results for phospholipid removal, followed by citric acid and lactic acid. In search for an explanation of the added value of the organic acids, Liang and Hulting hypothesized that the carboxylic groups of the acid were involved in the separation. Phospholipids may interact under the applied conditions ( $\mathrm{pH} 3$ ) with proteins via the basic amino acid residues and the polyanionic groups of the phospholipids. The presence of the carboxylic group of the organic acids may compete with the polyanionic groups of phospholipids [31]. However, in the present study, multiple lipid classes were present. Tzompa-Sosa et al. [31] showed by TLC analysis that insect lipids consist mainly of triglycerides [31]. These insects were killed rapidly $\left(30 \mathrm{~min}\right.$ at $-20^{\circ} \mathrm{C}$ followed by nitrogen immersion). The same results were obtained after blanching (98\% triglycerides) [30]. TLC analysis in the current study (data not shown) also indicated a major presence of triglycerides (no polyanionic group), thus implying that the interaction between proteins and lipids in this study is different. Although the specific context is different, both studies observe an added value of organic acids for separating the lipids present in biomass. Since the current study indicates lactic acid to be better than citric acid in removing the lipids, it could be stated that lactic acid has a higher preference toward neutral lipids. In addition, under the applied conditions ( $\mathrm{pH} 2)$, it is more likely that the acids were protonated (pKa of lactic acid is 3.08) and thus not negatively charged. The acidic $\mathrm{pH}$ may have stimulated the release of lipids from remaining tissue (located in pellet 1 when fractionating at neutral $\mathrm{pH}$ ) by, for example, changing the structure of bounded proteins. Nevertheless, $\mathrm{pH}$ cannot be the only explanation, as lactic acid was proven to be beneficial compared to the use of inorganic acids or other organic acids. This indicates that lactic acid has another beneficial effect in separating neutral lipids from other insect biomass components.

For the protein-enriched fraction (pellet 2), the use of organic acid did not increase the protein or lipid content in the fractions compared to water (condition 1) or $\mathrm{HCl}$ (condition 2). In comparison with condition 2 , there was no added value of the organic acids. The purity of the pellet 2 factions was maximal about $60 \%$ proteins, which is comparable to other protein extractions of the BSFL. For example, Bußler et al. [20] performed a hexane defatting resulting in a protein meal (still containing chitin) with a protein content of $44.9 \%$ and a crude fat content of $8.8 \%$. Osborne's fractionation after solvent lipid extraction created multiple fractions with a protein content range from 3 to 13\% [27]. Low-pressure defatting without the use of solvents resulted in a protein fraction containing 55\% proteins and $18 \%$ fat and high-pressure defatting resulted in a fraction with $67 \%$ crude proteins and $5 \%$ crude fat [33]. For other insects such as the mealworm, for example, an aqueous extraction at $\mathrm{pH} 10$ after a hexane extraction also delivered a protein fraction with $68 \%$ protein and $0.4 \%$ fat. Enzymatic extraction of proteins on crickets (Gryllodes sigillatus) did also not succeeded in obtaining a fraction higher than $70 \%$ of protein and $8 \%$ of fat [34]. Aqueous extraction of crickets (Acheta domesticus) resulted in multiple fractions comprising a fraction with $67 \%$ crude proteins and $14 \%$ crude fat [16].

\section{Reproducibility}

Extractions with $\mathrm{HCl}$ (condition 2), lactic acid (condition 4) and acetic acid (condition 5) were repeated in triplicate under slightly different conditions to evaluate the reproducibility. For condition 4, the first repetition was performed with freshly prepared juice; while for the second repetition, defrosted juice was used. Similar results were obtained (Fig. 3) indicating that the freezing and defrosting process does not affect the fractionation procedure. Conditions 1 and 5 were performed with a different type of centrifuge and showed the same fractionation profile for all fractions except for condition 5, fraction SN2. However, this difference can be explained by the differences in additions acid/base for $\mathrm{pH}$ changes and the volatility of acetic acid. Overall, all three conditions show good reproducibility of the process. In addition, the protocol was also successfully executed for another insect, viz., the lesser mealworm (data not shown).

\section{Solubility curve assessment}

Since most functional properties of proteins require the protein to be soluble $[35,36]$, the solubility was used as a criteria to evaluate potential use of the fractionated proteins as functional proteins. The total protein solubility of pellet 1, pellet 2 and SN2 are given in Fig. 4 . The proteins in the upper layer were not investigated for functional properties and were, therefore, not included in the calculations. These proteins were extracted in a highly hydrophobic environment (caused by the lipids) and were assumed to be insoluble in water or trapped in micelles in the lipid-rich fraction. Based on Fig. 4, it can be concluded that the acidic water treatment and acetic 
Fig. 3 Reproducibility: NDY distribution after fractionation for three conditions performed in duplicate with slightly different conditions (mean $\pm \mathrm{SD}$, $n=3$ ). NDY distribution over the obtained fraction after mixture was stirred at $100 \mathrm{rpm}$ for $30 \mathrm{~min}$ in a 17.6 liquid: solid (w:w) ratio (200 ml essay), condition 1: water, condition 4: lactic acid $+\mathrm{HCl}$, condition 5 : acetic acid $+\mathrm{HCl}$, centrifuge type 1: swing out centrifuge at room temperature, centrifuge type 2: angle head centrifuge at $25^{\circ} \mathrm{C}$
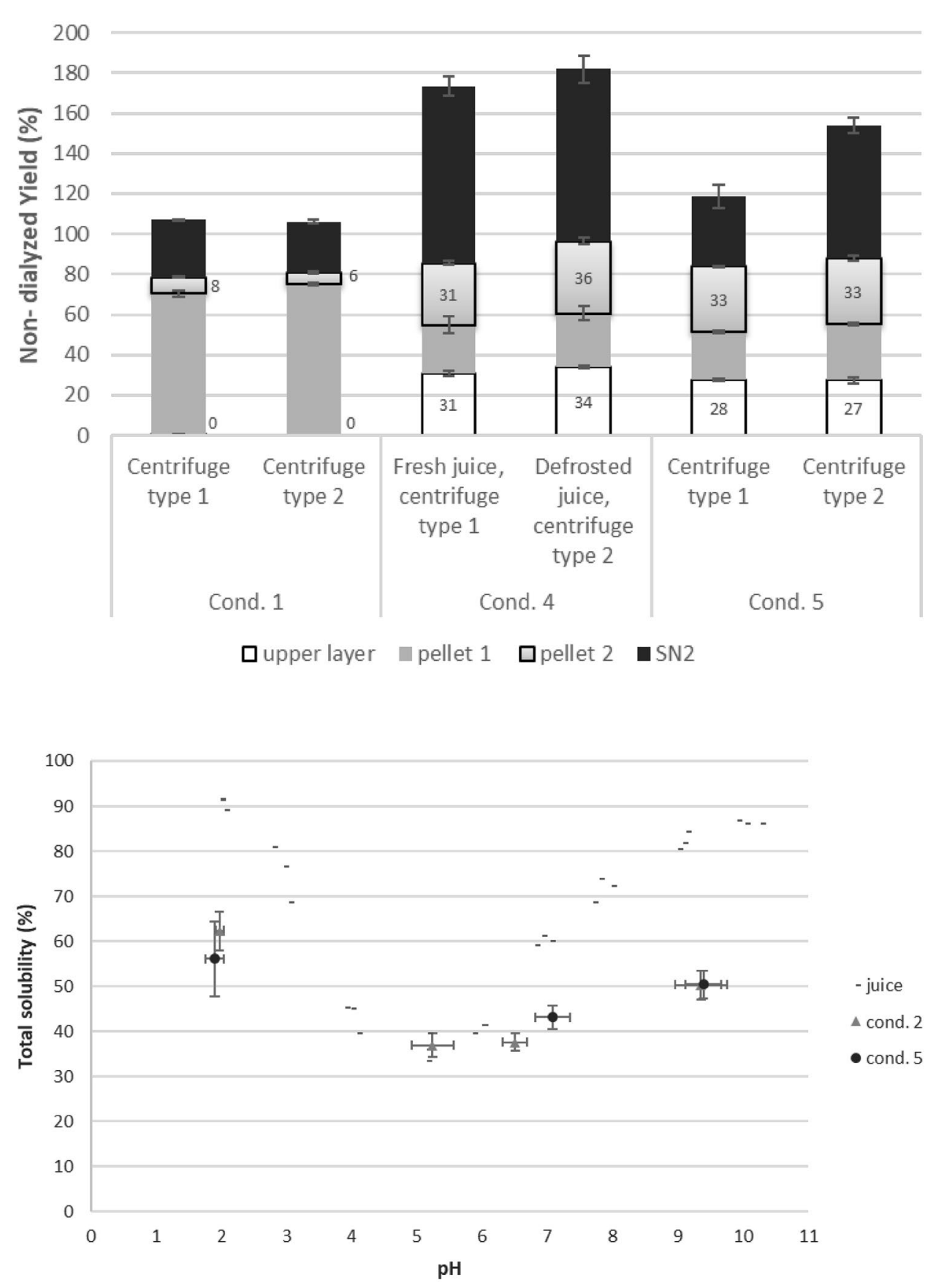

Fig. 4 Protein solubility as function of $\mathrm{pH}$ of defrosted juice, and the summarized solubility after fractionation of pellet 1, pellet 2 and SN2 from the BSFL in water. Summarized solubility of the obtained fraction after mixture was stirred at $100 \mathrm{rpm}$ for $30 \mathrm{~min}$ in a 17.6 liquid: solid (w:w) ratio (200 ml essay), condition 2: water $+\mathrm{HCl}$, condition 5: acetic $\mathrm{acid}+\mathrm{HCl}$ acid treatment resulted in soluble proteins, although partial loss in solubility was observed. At pH 2 and $9, \pm 35 \%$ of proteins were probably denatured or lost in the upper layer resulting in a lower solubility. At pH 5, no losses were measured for the inorganic acid treatment, and at $\mathrm{pH}$ 6.5-7 a loss of approximately $13-15 \%$ was recorded. No similar protein extractions of the BSFL were found in literature; however, data on extracted protein from the yellow mealworm were found. Protein extraction at $\mathrm{pH} 10$ after a defatting with ethanol resulted in $40 \%$ solubility at $\mathrm{pH} 7$ [12], similar to the results discussed here (Fig. 4). Bußler et al. [20] obtained a higher solubility, up to $60 \%$ at $\mathrm{pH}$ 7 , after alkaline extraction at $60^{\circ} \mathrm{C}$ and hexane defatting. The solubility of the separate fractions indicated that SN2 was most soluble (around $80 \%$ for $\mathrm{pH} \mathrm{2-5}$ and 7). The protein-enriched fraction (P2) had a high solubility at $\mathrm{pH}$ $2(60 \%)$ but extremely low at pH 5 and 7 (around 10\%). Yet, solubility experiment of SN1 indicated a solubility of $53 \%$ at $\mathrm{pH} 7$. This leads to the hypothesis that the acid environment did cause structural changes of the proteins but did not cause denaturation. Only when the $\mathrm{pH}$ was adjusted to $\mathrm{pH} 5$, the protein was denatured to a point 
where at neutral $\mathrm{pH}$, no renaturation could occur. Further investigation of other techno-functional properties beside the solubility is needed to evaluate the effect of the treatment more in detail.

\section{Conclusion}

The aim of this paper was to evaluate an alternative approach for fractionation of wet biomass. Organic acids were evaluated in this study to solubilize proteins. A special focus was given to additional benefits in the separation of lipids from proteins. Lipid- and protein-enriched fractions were achieved. All acids (organic and inorganic) enabled to obtain a lipid-rich fraction; however, the use of lactic acid combined with $\mathrm{HCl}$ proved to be the best condition to obtain a lipid fraction with a purity of $80 \%$ lipid. Multiple acids were capable to enrich the protein level in 1 fraction; however, when taking into account the yield and purity, acetic acid combined with $\mathrm{HCl}$ or $\mathrm{HCl}$ by itself gave best results. The purity of the enriched protein fraction reached $\pm 60 \%$. The data also implied that $\mathrm{pH}$ has a significant effect on lipid separation; whereas protein separation was less affected. The process proved to be robust and proteins were still partially soluble. The total proteins solubility after fractionation was in the same order of magnitude compared to other protein extraction procedures.

Acknowledgements The authors would like to acknowledge that this study has been funded by the BBI Joint Undertaking under the European Union's Horizon 2020 research and innovation program under Grant agreement No. 720715 (InDirect project).

\section{Compliance with ethical standards}

Conflict of interest The authors declare that they have no conflict of interest.

Compliance with ethics requirements All applicable international, national, and/or institutional guidelines for handling of the animals were followed.

Informed consent Informed consent was obtained from all individual participants included in the study.

Open Access This article is distributed under the terms of the Creative Commons Attribution 4.0 International License (http://creativeco mmons.org/licenses/by/4.0/), which permits unrestricted use, distribution, and reproduction in any medium, provided you give appropriate credit to the original author(s) and the source, provide a link to the Creative Commons license, and indicate if changes were made.

\section{References}

1. Nelson G, Rosegrant MW, Koo J, Robertson R, Sulser T, Zhu T, Ringler C, Msangi S, Palazzo A, Batka M, Magalh Ã£es M,
Santos, RA, Ewing M, Lee D (2009) Climate change: impact on agriculture and costs of adaptation. International Food Policy Research Institute (IFPRI). https://doi.org/10.2499/0896295354

2. van Huis A (2011) Potential of insects as food and feed in assuring food security. Annu Rev Entomol 58(2012):120928130709004

3. Foley JA et al (2011) Solutions for a cultivated planet. Nature 478(7369):337-342

4. van Huis A, Itterbeeck JV, Klunder H, Mertens E, Halloran A, Muir G, Vantomme P (2013) Edible insects: Future prospects for food and feed security. Food and Agriculture Organization of the United Nations, Rome. https://doi.org/10.1017/CBO9781107 415324.004

5. Oonincx DGAB, Van Broekhoven S, Van Huis A, Van Loon JJA (2015) Feed conversion, survival and development, and composition of four insect species on diets composed of food by-products. PLoS One 10(12): 0144601

6. Spranghers T, Ottoboni M, Klootwijk C, Ovyn A, Deboosere S, De Meulenaer B, Michiels J, Eeckhout M, De Clercq P, De Smet S (2016) Nutritional composition of black soldier fly (Hermetia illucens) prepupae reared on different organic waste substrates. J Sci Food Agric. https://doi.org/10.1002/jsfa.8081

7. EFSA Scientific Committee (2015) Risk profile related to production and consumption of insects as food and feed. EFSA J 13(10):60

8. Ramachandran Nair K, Mathew P, Madhavan P, Prabhu P (1987) Chitin as a feed additive for broiler chicken. Indian J Poultry Sci 22(10):40-44

9. Ozimek L, Sauer WC, Kozikowski V, Ryan JK, Jorgensen H, Jelen P (1985) Nutritive value of protein extracted from honey bees. J Food Sci 50(5):1327-1329

10. Marono S et al (2015) In vitro crude protein digestibility of Tenebrio molitor and Hermetia illucens insect meals and its correlation with chemical composition traits. Ital J Anim Sci 14(3):338-343

11. Kroeckel S et al (2012) When a turbot catches a fly: evaluation of a pre-pupae meal of the black soldier fly (Hermetia illucens) as fish meal substitute-Growth performance and chitin degradation in juvenile turbot (Psetta maxima). Aquaculture 364-365:345-352

12. Zhao X, Vázquez-Gutiérrez JL, Johansson DP, Landberg R, Langton M (2016) Yellow mealworm protein for food purposesextraction and functional properties. PLoS One 11(2):1-17

13. Nongonierma AB, FitzGerald RJ (2017) Unlocking the biological potential of proteins from edible insects through enzymatic hydrolysis: a review. Innov Food Sci Emerg Technol 43(March):239-252

14. Zielińska E, Karaś M, Baraniak B (2018) Comparison of functional properties of edible insects and protein preparations thereof. LWT Food Sci Technol 91:168-174

15. Purschke B, Tanzmeister H, Meinlschmidt $P$, Baumgartner $S$, Lauter K, Jäger H (2018) Recovery of soluble proteins from migratory locust (Locusta migratoria) and characterisation of their compositional and techno-functional properties. Food Res Int 106:271-279

16. Ndiritu AK, Kinyuru JN, Kenji GM, Gichuhi PN (2017) Extraction technique influences the physico-chemical characteristics and functional properties of edible crickets (Acheta domesticus) protein concentrate. J Food Meas Charact 11(4):2013-2021

17. Purschke B, Stegmann T, Schreiner M (2017) Pilot-scale supercritical $\mathrm{CO}_{2}$ extraction of edible insect oil from Tenebrio molitor L. larvae-influence of extraction conditions on kinetics, defatting performance and compositional properties. Eur J Lipid Sci Technol 119(2):1-12. https://doi.org/10.1002/ejlt.201600134

18. Wu S (2012) Supercritical carbon dioxide extraction of oil from Clanis bilineata (Lepidoptera), an edible insect. Afr J Biotechnol 11(20):4607-4610. https://doi.org/10.5897/AJB11.4102 
19. Yi L, Lakemond CMM, Sagis LMC, Eisner-Schadler V, van Huis A, van Boekel MAJS (2013) Extraction and characterisation of protein fractions from five insect species. Food Chem 141(4):3341-3348. https://doi.org/10.1016/j.foodc hem.2013.05.115

20. Bußler S, Rumpold BA, Jander E, Rawel HM, Schlüter OK (2016) Recovery and techno-functionality of flours and proteins from two edible insect species: Meal worm (Tenebrio molitor) and black soldier fly (Hermetia illucens) larvae. Heliyon 2(12):e00218

21. Ivanovs K, Blumberga D (2017) Extraction of fish oil using green extraction methods: a short review. Energy Procedia 128:477-483

22. Kinyuru JN, Kenji GM, Njoroge SM, Ayieko M (2010) Effect of processing methods on the in vitro protein digestibility and vitamin content of edible winged termite (Macrotermes subhylanus) and grasshopper (Ruspolia differens). Food Bioprocess Technol 3(5):778-782

23. L'Hocine L, Boye JI, Arcand Y (2006) Composition and functional properties of soy protein isolates prepared using alternative defatting and extraction procedures. J Food Sci 71(3):C137-C145

24. Sarwar-Gilani G, Wu-Xiao C, Cockell KA (2012) Impact of antinutritional factors in food proteins on the digestibility of protein and the bioavailability of amino acids and on protein quality. $\mathrm{Br} \mathrm{J}$ Nutr 108(S2):S315-S332

25. Liang Y, Hultin HO (2005) Separation of membranes from acidsolubilized fish muscle proteins with the aid of calcium ions and organic acids. J Agric Food Chem 53(8):3008-3016

26. Janssen RH, Vincken JP, Van Den Broek LAM, Fogliano V, Lakemond CMM (2017) Nitrogen-to-protein conversion factors for three edible insects: Tenebrio molitor, Alphitobius diaperinus, and Hermetia illucens. J Agric Food Chem 65(11):2275-2278

27. Caligiani A et al (2018) Composition of black soldier fly prepupae and systematic approaches for extraction and fractionation of proteins, lipids and chitin. Food Res. Int. 105:812-820

28. Gilani GS, Xiao CW, Cockell KA (2012) Impact of antinutritional factors in food proteins on the digestibility of protein and the bioavailability of amino acids and on protein quality. Br J Nutr 108(Suppl. 2):S315-S332

29. Ushakova NA, Brodskii ES, Kovalenko AA, Bastrakov AI, Kozlova AA, Pavlov ADS (2016) Characteristics of lipid fractions of larvae of the black soldier fly Hermetia illucens. Dokl Biochem Biophys 468(1):462-465. https://doi.org/10.1134/S1607 672916030145

30. Caligiani A et al (2019) Influence of the killing method of the black soldier fly on its lipid composition. Food Res Int 116:276-282

31. Tzompa-Sosa DA, Yi L, van Valenberg HJF, van Boekel MAJS, Lakemond CMM (2014) Insect lipid profile: aqueous versus organic solvent-based extraction methods. Food Res Int 62:1087-1094

32. Liang Y, Hultin HO (2005) Separation of muscle membrane from alkali-solubilized fish muscle proteins. J Agric Food Chem 53(26):10012-10017

33. Schiavone A et al (2017) Nutritional value of a partially defatted and a highly defatted black soldier fly larvae (Hermetia illucens L.) meal for broiler chickens: apparent nutrient digestibility, apparent metabolizable energy and apparent ileal amino acid digestibility. J Anim Sci Biotechnol 8(1):1-9

34. Hall FG, Jones OG, O'Haire ME, Liceaga AM (2017) Functional properties of tropical banded cricket (Gryllodes sigillatus) protein hydrolysates. Food Chem 224:414-422

35. Nakai S, Li-Chan E (1985) Structure modification and functionality of whey proteins: quantitative structure-activity relationship approach. J Dairy Sci 68(10):2763-2772

36. Pelegrine DHG, Gasparetto CA (2005) Whey proteins solubility as function of temperature and $\mathrm{pH}$. LWT Food Sci. Technol. 38(1):77-80

Publisher's Note Springer Nature remains neutral with regard to jurisdictional claims in published maps and institutional affiliations. 